http://journal.nafo.int

J. Northw. Atl. Fish. Sci., Vol. 6: 117-124

\title{
Energy Equivalents of Marine Organisms from the Continental Shelf of the Temperate Northwest Atlantic
}

\author{
Frank W. Steimle Jr. and Russell J. Terranova \\ National Marine Fisheries Service, Northeast Fisheries Center \\ Sandy Hook Laboratory, Highlands, N. J. 07732, USA
}

\begin{abstract}
The availability of appropriate energy equivalents is one of the needs in species or community bioenergetic models. Energyequivalent data for 151 common invertebrate and vertebrate species on the continental shelf of the temperate Northwest Atlantic from Nova Scotia to North Carolina are presented and compared with the more limited results of other studies. Energy equivalents were found to be variable among major taxonomic or trophic groups and general trends were not evident. A review of equivalents from some recent ecosystem models for the Northwest AtInatic indicates that the models can be substantially improved.
\end{abstract}

\section{Introduction}

Energy budgets or trophodynamic models are being developed and used for the Northwest Atlantic region and elsewhere to examine theoretical functions and linkages of ecosystem components and the structure of ecosystems or communities (e.g. Walsh, 1981; Pace et al., 1984). Particular interest has been shown in models that are related to fish production, especially in the Northwest Atlantic (Mills and Fournier, 1979; Cohen et al., 1982; Sissenwine et al., 1984). Most of these models or budgets are still quite crude and are based on limited data and assumptions of unknown validity. Often these assumptions are borrowed from earlier models without much evaluation and they vary significantly among the models for various reasons. Common assumptions in many models relate to the energy-equivalent values that are applied to the standing stocks (biomass) of major trophic groups or communities. Usually, the equivalents are based on data for a limited number of species, phyla or samples (Brawn et al., 1968; Tyler, 1973), or for areas that may not be representative of the region being studied (Thayer et al., 1973; Wissing et al., 1973; Atkinson and Wacasey, 1976, 1983).

Despite the problems that are associated with ecosystem modelling, the availability of specific energy equivalents from replicate sampling for a wide range of taxa should be of benefit, especially for comparing different ecosystems. The purpose of this paper is twofold. The first provides an extensive set of original energy-equivalents data, based on bomb calorimetry for 151 species representing 11 phyla, which in concert with data from other relevant studies, cover almost all major groups (with emphasis on larger nektonic and benthic species) that are common in temperate waters of the Northwest Atlantic. The second objective is to reexamine (a) several trends that have been suggested by previous studies of equivalents relating to evolution or habitat, and (b) many of the assumed energy equivalents that have been used in recently-published energy-based ecosystem models.

\section{Materials and Methods}

Organisms for this study were collected by various means from the continental shelf between Nova Scotia and North Carolina. Species were selected for analysis on the basis of their relative contribution to energy pools and budgets of the shelf, i.e. they comprise significant standing stocks (Wigley and Theroux, ;1981), or because they are food for many fishery resource species (Edwards and Bowman, 1979). For each species, the most common sizes of animals in the collections or in the stomachs of predators were selected for analysis. Whole bodies were analyzed except in the case of larger predators (i.e. sharks) where samples were represented by vertical sections (slices) when it was impractical to process the entire animals. The data for these sections were not mixed with data for whole bodies in computing mean values. The gastrointestinal tract contents were not purged or removed from the animals before processing, fully understanding the potential variability that this could cause. Most molluscs were removed from their shells and only the meats analyzed, in which cases the mean shell weights were used to estimate whole body values. However, some small species of molluscs were analyzed with their shells. Taxonomic nomenclature and organization of species and groups are based on Gosner (1971) for invertebrates and Robins et al. (1980) for fish.

Samples for analysis (usually a minimum of five similar-sized individuals per species per sample) were frozen immediately after collection. Within 60 days, the individual samples were either homogenized and aliquots removed or placed whole (in the case of small organisms) in a vacuum dryer and dried at room temperature to constant weight. These homogenized or dried samples were pulverized in a mill to fine 
powder and compressed into 1.0 or $0.1 \mathrm{~g}$ pellets. The pellets were combusted in a Parr Model 1241 Adiabatic Calorimeter with the use of 1108 standard or 1107 semimicro oxygen bombs, depending on the size of the sample. The recommended procedures of Parr Instrument Company (Anon, 1981a, 1982) were followed closely. Usually, five replicate pellet combustions were made for each species, but additional combustions were made when the variability around the mean of five values exceeded $5 \%$ and sample material was still available. Acid corrections were not determined because the anticipated error due to this factor is usually less than 2\% (Paine, 1964, 1971).

To calculate wet-weight values of equivalents, duplicate fresh subsamples were weighed, dried at $100^{\circ} \mathrm{C}$ for $12 \mathrm{hr}$, and reweighed to determine moisture content. To calculate ash-free dry weights, vacuumdried material was weighed, burned in a muffle oven at $500^{\circ} \mathrm{C}$ for $4-5 \mathrm{hr}$, and reweighed to determine ash content. These ash samples were replaced in the oven and reburned at $900^{\circ} \mathrm{C}$ for an additional $4 \mathrm{hr}$ to estimate $\mathrm{CaCO}_{3}$ content by weight loss through degradation to $\mathrm{CO}_{2}$.

Calculations to determine energy equivalents were based on Parr Instrument Company and American Society for Testing and Materials (ASTM) standards (Anon., 1970, 1981b). Benzoic acid $(<5 \%)$ was added to some samples with high ash content to insure complete combustion. Samples, which were found to contain $25 \%$ or more of $\mathrm{CaCO}_{3}$ (total dry weight), were corrected for endothermic $\mathrm{CaCO}_{3}$ breakdown during combustion on the basis of ash-loss corrections that were suggested by Atkinson and Wacasey (1976, 1983).

\section{Results and Discussion}

The mean energy equivalents (wet weight and ashfree dry weight) for all major animal phyla or trophic groups are presented separately for pelagic and benthic types (Table 1), together with summary data from other available studies pertinent to the western North Atlantic for comparison. Data on seasonal variability in the ash-free dry-weight energy equivalents for 21 selected species are listed in Table 2. The basic data, representing more than 1400 combustions for 151 species, are listed in the Appendix to this paper.

The results from this study of energy equivalents indicate significant differences in mean values among major taxa (Table 1), especially with regard to the wetweight values (range $0.25-6.30 \mathrm{KJ} / \mathrm{g}$ ). Ash-free dry weights, with two exceptions (octocorals and cetaceans), exhibit a relatively narrow range (18.2-26.5 $\mathrm{KJ} / \mathrm{g}$ ). This range and the distribution of values are comparable to ranges and distributions that were reported by Cummins and Wuycheck (1971), Thayer et al. (1973) and Griffiths (1977).

The variability of equivalents among major taxa has been ascribed to evolutionary differences (Thayer et al., 1973), but this is not evident from Table 1 on a wet-weight or ash-free dry-weight basis. Some of the variability has been linked to species habitat preference, such as benthic versus pelagic (Wissing et al., 1973), but this is also not fully supported by the data in Table 1. For example, on a wet-weight basis, their idea is probably true for molluscs and fish but not for cnidarians, crustaceans and tunicates. However, Wissing et al. (1973) examined many larval or planktonic forms that were not included in the present study. For the ash-free dry-weight values, there is little within-phyla difference between pelagic and benthic taxa, especially when the high standard deviations from the means are considered. However, crustaceans are an exception, as was found also by Griffiths (1977).

The relatively large standard deviations (SD) that are associated with much of the summarized data (Table 1) and some of the specific data (Appendix) may be attributable to a variety of factors. There were significant seasonal differences in the energy equivalents for some species in this study, usually related to gonadal development, but not for all (Table 2). According to Griffiths (1977) and Schroeder (1977), other factors that may influence energy equivalents are life-history stage, size range, molting stage, temporal scales other than season, climatic zone, ash content, and human error. The factors which are applicable to particular groups vary and are not always consistent in the direction of influence. More information is needed about the influences of these factors on specific taxonomic groups to make the best use of data on energy equivalents when very accurate values are required. Most researchers appear to be satisfied with the current level of accuracy, but, as the variables become better defined, the accuracy of energy data will become more important.

Significant improvement in ecosystem modelling may be achieved with the use of group-specific or species-specific energy equivalents. For example, energy budgets have been postulated for western North Atlantic regions on the basis of a general macrofauna biomass-conversion of $0.6 \mathrm{Kcal}(2.5 \mathrm{KJ} / \mathrm{g})$ wet weight (Mills and Fournier, 1979; Walsh, 1981). With the use of results of the extensive benthic study of the Middle Atlantic by Wigley and Theroux (1981), conversion of the biomass composition of the major taxa $(71 \%$ molluscs, $12 \%$ echinoderms, $7 \%$ polychaetes, $5 \%$ crustaceans, and $5 \%$ others) to energy from the data in Table 1 yields an average value of about $3.2 \mathrm{KJ} / \mathrm{g}$ wet weight or about $0.8 \mathrm{Kcal}$, a $30 \%$ increase. This value may still be conservative because it is based on an $83 \%$ contribution of molluscs ( $99 \%$ shelled) and echino- 
TABLE 1. Mean energy equivalences (with standard deviations, SD) for major taxonomic or trophic groups on the continental shelf from Nova Scotia to North Carolina, with comparable wet-weight and ash-free dried-weight values from other studies.

\begin{tabular}{|c|c|c|c|c|c|}
\hline \multirow[b]{2}{*}{ Group } & \multirow{2}{*}{$\begin{array}{l}\text { No. of } \\
\text { species }\end{array}$} & \multicolumn{2}{|c|}{ Wet weight $(\mathrm{KJ} / \mathrm{g})$} & \multicolumn{2}{|c|}{ Ash-free dried weight $(\mathrm{KJ} / \mathrm{g})$} \\
\hline & & Mean (SD) & Comparable & Mean (SD) & Comparable \\
\hline Porifera & 1 & 1.51 & - & 24.20 & $22.21^{\mathrm{a}} 25.27^{\mathrm{b}}$ \\
\hline \multicolumn{6}{|l|}{ Cnidarià } \\
\hline Hydrozoids & 1 & 1.85 & - & 18.97 & $21.30^{\mathrm{a}}$ \\
\hline Octocorals & 1 & 2.70 & $2.07^{c}$ & 10.70 & $21.56^{\mathrm{a}}$ \\
\hline Anemones & 2 & $3.43(1.27)$ & $1.33^{\mathrm{d}}$ & $20.80(0.71)$ & $24.72^{\mathrm{c}}$ \\
\hline Medusae & 2 & $0.25(0.21)$ & - & $18.90(3.68)$ & $17.13^{\mathrm{e}}$ \\
\hline Ctenophores & - & - & $0.21^{t}$ & - & $15.73^{e} 16.73^{t}$ \\
\hline Platyhelmenthes & - & - & $5.56^{c}$ & - & $11.15-26.69^{c}$ \\
\hline Rhynchocoels & 1 & 4.60 & - & 23.25 & $22.28^{\mathrm{a}}$ \\
\hline Chaetognaths & - & - & - & - & $24.32^{9}$ \\
\hline Bryozoans & 1 & 2.30 & - & 26.50 & $16.61^{a}$ \\
\hline Brachiopods & 1 & 2.50 & - & - & $18.40^{\mathrm{c}} 21.23^{\mathrm{a}}$ \\
\hline \multicolumn{6}{|l|}{ Molluscs } \\
\hline Bivalves & 10 & $1.54(0.77)^{\prime}$ & $1.32^{h}$ & $21.69(1.71)$ & $22.88^{\mathrm{t}} 23.04^{\mathrm{a}}$ \\
\hline Gastropods & 7 & $2.28(0.88)^{\prime}$ & $1.97^{\mathrm{n}}$ & $21.17(1.03)$ & $24.27^{\mathrm{a}} 19.10^{\mathrm{h}}$ \\
\hline Cephalopods & 4 & $5.50(1.65)$ & $4.39^{t}$ & $22.90(1.47)$ & $23.26^{\mathrm{e}} 26.53^{\prime}$ \\
\hline Polychaetes & 11 & $4.58(1.58)$ & $2.68^{\mathrm{c}} 2.82^{\mathrm{h}} 3.56^{\mathrm{d}}$ & $21.85(3.45)$ & $19.66^{\mathrm{c}} 23.04^{\mathrm{a}}$ \\
\hline Sipunculids & - & - & $2.49^{c}$ & - & $22.96^{\mathrm{a}}$ \\
\hline \multicolumn{6}{|l|}{ Crustaceans } \\
\hline Zooplankton & - & - & $1.64^{\mathrm{c}}$ & - & $23.08^{\mathrm{C}} 27.60^{\mathrm{e}}$ \\
\hline Benthic malacostraca & 20 & $5.40(2.49)$ & $4.30^{\mathrm{c}, \mathrm{f}}$ & $20.74(5.17)$ & $17.37^{\mathrm{e}} 22.63^{\mathrm{a}} 21.60^{\mathrm{c}, \mathrm{f}}$ \\
\hline Pelagic malacostraca & 3 & $3.50(0.14)$ & $4.06^{\mathrm{h}}$ & $24.80(0.14)$ & $23.01^{\mathrm{n}} 31.52^{\mathrm{e}}$ \\
\hline \multicolumn{6}{|l|}{ Echinoderms } \\
\hline Holothuroids & 3 & $4.77(3.37)$ & $0.81^{\mathrm{c}}$ & $20.30(3.46)$ & $14.85^{\mathrm{i}} 25.50^{\mathrm{a}}$ \\
\hline Echinoids & 4 & $1.32(0.78)$ & $0.20^{t} 1.20^{c}$ & $25.82(2.53)$ & $23.64^{\mathrm{a}} 26.84^{\mathrm{c}}$ \\
\hline Stelleroids & 6 & $2.57(0.63)$ & $2.13^{\prime} 2.42^{c}$ & $19.10(3.19)$ & $17.91^{\mathrm{c}} 23.68^{\mathrm{a}}$ \\
\hline \multicolumn{6}{|l|}{ Tunicata } \\
\hline Benthic & 4 & $2.25(1.34)$ & $0.92^{\prime}$ & $19.38(7.02)$ & $18.44-21.00^{\mathrm{a}} 25.27^{\mathrm{t}}$ \\
\hline Pelagic & 1 & 0.40 & $0.29^{1}$ & 18.20 & $22.97^{\mathbf{e}}$ \\
\hline \multicolumn{6}{|l|}{ Pisces } \\
\hline Demersal & 32 & 4.77 & $4.42^{\mathrm{c}} 5.13^{t}$ & $22.96(2.30)$ & $22.16^{\mathrm{c}} 24.06^{\dagger} 25.94^{\mathrm{a}}$ \\
\hline Pelagic & 27 & 6.30 & $6.11^{b} 6.76^{t} 8.06^{c}$ & $24.22(2.15)^{\mathrm{m}}$ & $23.56^{\prime} 25.13^{\prime}$ \\
\hline Cetacea & 1 & - & $4.8^{-26.4^{\circ}}$ & $33.65^{n}$ & $12.7-32.3^{\circ}$ \\
\hline \multirow{2}{*}{\multicolumn{2}{|c|}{$\begin{array}{l}\text { Atkinson and Wacasey (1976). } \\
\text { Atkinson and Wacasey (1983). }\end{array}$}} & \multirow{2}{*}{\multicolumn{2}{|c|}{$\begin{array}{l}\text { b Griffiths (1977). } \\
\text { e Wissing et al. (1973). }\end{array}$}} & \multicolumn{2}{|c|}{${ }^{\circ}$ Cummins and Wuycheck (1971). } \\
\hline & & & & \multirow{2}{*}{\multicolumn{2}{|c|}{$\begin{array}{l}\text { Thayer et al. (19/3). } \\
\text { Kitchell et al. (1977). }\end{array}$}} \\
\hline \multicolumn{2}{|c|}{${ }^{9}$ Hopkins et al. (1978). } & \multicolumn{2}{|l|}{${ }^{\text {h }}$ Tyler (1973). } & & \\
\hline \multicolumn{2}{|c|}{ ' Lawrence and Kafri (1979). } & \multicolumn{4}{|c|}{ " Musaeva and Sokolova (1979). } \\
\hline \multicolumn{6}{|c|}{$\begin{array}{l}\text { 'Means calculated from whole animals and meat values with appropriate shell weight added. } \\
\text { m Equivalences for sections of large predators, not included in the mean for whole pelagic fish are about } 24.1 \mathrm{KJ} / \mathrm{g} \text {. } \\
\text { " Sample not representative of whole animal. } \\
\text { o Slice from anterior ventral aroove area and posterior dorsal area of fin whale (Lockver et al 1984). }\end{array}$} \\
\hline
\end{tabular}

derms $(60 \%$ echinoid) with relatively low energy equivalents. Another example is that for fish by Sissenwine et al. (1984), who used conversion of $1 \mathrm{~g}$ (wet weight) = $1 \mathrm{Kcal}(4.2 \mathrm{KJ} / \mathrm{g})$ for all fish in their budget. The results in Table 1 indicate a mean value of about $4.8 \mathrm{KJ} / \mathrm{g}$ for demersal species and about $6.3 \mathrm{KJ} / \mathrm{g}$ for pelagics. The resultant average $(5.6 \mathrm{KJ} / \mathrm{g})$, based on almost equal contributions of demersal and pelagic species from the estimates of Sissenwine et al. (1984), indicates that the amount of energy in the fish pool of their Georges Bank budget was underestimated by as much as $30 \%$.
Most energy budgets are still crude, and the variables are often inaccurate by a factor of 2 or more. The use of a more accurate value for biomass conversion to energy may not make much of a difference until the accuracy of related variables are also improved. Attempts were made to substitute the present energy data in several published models to see if the conclusions might be altered, but the information in those papers was not sufficiently specific. At present, the types of studies that would benefit most from the availability of more accurate energy equivalents for specific 
TABLE 2. Mean seasonal energy equivalences and spawning period for selected species on the continental shelf from Nova Scotia to North Carolina. (" indicates differences significant at the $P=0.05$ level.)

\begin{tabular}{|c|c|c|c|c|c|}
\hline \multirow[b]{2}{*}{ Species } & \multicolumn{4}{|c|}{ Ash-free dry-weight $(\mathrm{KJ} / \mathrm{g})$} & \multirow[b]{2}{*}{ Spawning period } \\
\hline & Winter & Spring & Summer & Autumn & \\
\hline \multicolumn{6}{|l|}{ Anthozoa } \\
\hline Cerianthiopsis americanus & 21.1 & - & 21.7 & - & $?$ \\
\hline \multicolumn{6}{|l|}{ Polychaeta } \\
\hline Aphrodita hastata & - & 18.9 & 19.2 & $21.1^{\star}$ & $?$ \\
\hline Nephtys incisa & - & 23.5 & 18.2 & $21.0^{*}$ & Spring and autumn \\
\hline Pherusa affinus & 24.0 & 27.3 & 21.8 & $21.7^{\star}$ & Primarily spring \\
\hline \multicolumn{6}{|l|}{ Mollusca } \\
\hline Illex illecebrosus & 24.6 & - & 22.6 & - & Winter \\
\hline Loligo pealei & 20.9 & 23.2 & 21.5 & $21.9^{*}$ & Late spring \\
\hline Placopecten magellanicus & - & 22.1 & 20.8 & 22.6 & Autumn \\
\hline \multicolumn{6}{|l|}{ Crustacea } \\
\hline Hyas areneus & - & 13.9 & - & 20.5 & Winter \\
\hline Libinia emarginata & - & 17.1 & - & 21.5 & Summer-early autumn \\
\hline Meganyctiphanes norvegica & - & 24.2 & 26.6 & $24.0^{*}$ & Winter and spring \\
\hline \multicolumn{6}{|l|}{ Echinodermata } \\
\hline Echinarachnius parma & - & 15.3 & 25.5 & $31.9^{\star}$ & Autumn \\
\hline Ophiopholis aculeata & - & 10.9 & - & 16.9 & $?$ \\
\hline \multicolumn{6}{|l|}{ Pisces } \\
\hline Alosa aestivalis & - & 21.5 & 25.7 & $24.3-29.3^{\star}$ & Late spring-early summer \\
\hline Alosa pseudoharengus & 26.6 & - & 24.0 & $23.9^{\star}$ & Spring \\
\hline Ammodytes americanus & - & 25.5 & 20.4 & $26.5^{\star}$ & Autumn-winter \\
\hline Anchoa hepsetus & - & 22.8 & 22.2 & 25.5 & Late spring \\
\hline Limanda ferruginea & - & 21.8 & 23.9 & 18.2 & Spring-summer \\
\hline Macrozoarces americanus & - & 21.5 & 22.7 & 22.4 & Autumn \\
\hline Peprilus triacanthus & - & 28.6 & 29.7 & 26.3 & Summer-autumn \\
\hline Sebastes sp. & 23.1 & 20.4 & 25.8 & - & Summer \\
\hline Stenotomus chrysops & - & 24.2 & 25.7 & 28.1 & Spring-summer \\
\hline
\end{tabular}

components of communities are those which use crude wet or dry weight biomass as the basic unit in estimates of production (Rowe, 1971) or for comparing different ecosystems (Walsh, 1981; Petersen, 1984). The energy equivalents in this paper, although probably requiring further study to fully assess the specific causes and the significance of data variability, should enable more realistic assessments and conclusions in studies that require energy equivalents, especially in the western North Atlantic.

Energy equivalents are presented in this paper for most of the taxonomic or trophic groups which are common on the continental shelf from Nova Scotia to North Carolina. These data show that variability among groups is important and should be included in any conversion of biomass to energy to avoid potentially significant errors. The use of energy equivalents for specific taxa or trophic groups can improve the realism of many energy budgets, production estimates, and comparisons of different ecosystems. However, there is still a high degree of variability in the available equivalents. This is probably a function of the condition (age, reproductive stage, health, etc.) of the species being analyzed, environmental conditions, variation in methodology for different animals, and number of samples.

\section{Acknowledgements}

We thank John B. Pearce and Marvin Grosslein for their support and encouragement during this study; Thomas Wilhelm, Charles Idleburger and Al Witik for their invaluable assistance in the Laboratory; Donald Flescher and Charles Stillwell for providing many of the samples; Maureen Montone, Alicia Gruber and Kathe Melkers for typing the various drafts and the tables; and the late David Frame for introducing the senior author to energy studies. The many comments of Anthony Pacheco, unidentified reviewers and the editors greatly improved this paper.

\section{References}

ANON. 1970. Oxygen bomb calorimetry and combustion methods. Parr Instrument Co., Moline, III., Manual No. $130,56 \mathrm{p}$.

1981a. Instructions for 1241 adibatic calorimeters. Parr Instrument Co., Moline, III., Manual No. 160, 26 p.

1981b. ASTM standards for bomb calorimetry and combustion methods. American Society for Testing and Materials, Philadelphia, Penn., $56 \mathrm{p}$.

1982. Instructions for semimicro operation of series 1240 oxygen bomb calorimeters. Parr Instrument Co., Moline, III., $19 \mathrm{p}$.

ATKINSON, E. G., and J. W. WACASEY. 1976. Caloric values 
of zoobenthos and phytobenthos from the Canadian Arctic. Can. Fish. Mar. Serv. Tech. Rep., 632: 24 p.

1983. Caloric equivalents for benthic marine organisms from the Canadian Arctic. Can. Tech. Rep. Fish. Aquat. Sci., 1216: $31 \mathrm{p}$

BRAWN, V. M., D. L. PEER, and R. J. BENTLEY. 1968. Caloric content of the standing crop of benthic and epibenthic invertebrates of St. Margaret's Bay, Nova Scotia. J. Fish. Res. Board Can., 25: 1803-1811.

COHEN, E. B., M. D. GROSSLEIN, M. P. SISSENWINE, F. W. STEIMLE, and W. R. WRIGHT. 1982. Energy budget of Georges Bank. Can. Spec. Publ. Fish. Aquat. Sci., 59: 95-107.

CUMMINS, K. W., and J. C. WUYCHECK. 1971. Caloric equivalents for investigations in ecological energetics. Int. Ver. Theor. Angew. Limno. Verh., 18: 1-158.

EDWARDS, R. L., and R. E. BOWMAN. 1979. Food consumed by continental shelf fishes. In Predator-prey systems in fishery management (p. 387-406), H. Clepper (ed.), Sport. Fish. Inst., Washington, D.C., 504 p.

GOSNER, K. L. 1971. Guide to identification of marine and estuarine invertebrates, Cape Hatteras to the Bay of Fundy. Wiley-Interscience, New York, N.Y., 693 p.

GRIFFITHS, D. 1977. Caloric variation in Crustacea and other animals. J. Anim. Ecol., 46: 593-605.

HOPKINS, C. C. E., S. FALK-PETERSEN, and K. TANDE. 1978. A preliminary study of zooplankton sound scattering layers in Balsfjorden: structure, energetics and migrations. Sarsia, 63: 255-264.

KITCHELL, J. F., J. J. MAGNUSON, and W. H. NEILL. 1977 Estimation of caloric content for fish biomass. Environ. Biol. Fish., 2: 185-188.

LAWRENCE, J. M., and J. KAFRI. 1979. Numbers, biomass and caloric content of the echinoderm fauna of the rocky shores of Barbados. Mar. Biol., 52: 87-91.

LOCKYER, C. H., L. C. MCCONNELL, and T. D. WATERS. 1984. The biochemical composition of fin whale blubber. Can. J. Zool., 62: 2553-2562.

MILLS, E. L., and R. O. FOURNIER. 1979. Fish production and the marine ecosystem of the Scotian Shelf, eastern Canada. Mar. Biol., 54: 101-108.

MUSAEVA, E. I., and I. A. SOKOLOVA. 1979. Caloricity of planktonic animals from the Pacific Ocean. Okenologia, 19(1): 146-149.

PACE, M. L., J. E. GLASSER, and L. R. POMEROY. 1984. A simulation analysis of continental shelf food webs. Mar. Biol., 82: 47-63.

PAINE, R. T. 1964. Ash and caloric determinations of sponge and opisthobranch tissue, Ecology, 45: 384-387.

1971. The measurement and application of the calorie to ecological problems. Annu. Rev. Ecol. Syst., 2: 145-164.

PETERSEN, G. H. 1984. Energy flow in comparable aquatic ecosystems from different climatic zones. ICES Rapp. Proc.-Verb., 183: 119-125.

ROBINS, C. R., R. M. BAILEY, C. E. BOND, J. R. BROOKER, E. A. LACHNER, R. N. LEAR, and W. B. SCOTT. 1980. A list of common and scientific names of fishes from the United States and Canada. Spec. Publ. Amer. Fish. Soc., No. 12 (4th edition), $174 \mathrm{p}$.

ROWE, G. T. 1971. Benthic biomass and surface productivity. In Fertility of the sea (p. 441-454), J. D. Costlow (ed.), Gordon and Breach, New York, N. Y., Vol. 2, p. 309-622.

SCHROEDER, L. A. 1977. Caloric equivalents of some plant and animal material. Oecologia, 28: 261-267.

SISSENWINE, M. P., E. B. COHEN, and M. D. GROSSLEIN. 1984. Structure of the Georges Bank ecosystem. ICES Rapp. Proc.-Verb., 183: 243-254.

THAYER, G. W., W. E. SCHAFF, J. W. ANGELOVIC, and M. W. LaCROIX. 1973. Caloric measurements of some estuarine organisms. Fish. Bull. U.S., 71: 289-296.

TYLER, A. V. 1973. Caloric values of some North Atlantic invertebrates. Mar. Biol., 19: 258-261.

WALSH, J. J. 1981. Shelf-sea ecosystems. In Analysis of marine ecosystems (p. 159-196), A. R. Longhurst (ed.), Academic Press, New York, N. Y., 741 p.

WIGLEY, R. L., and R. B. THEROUX. 1981. Atlantic continental shelf and slope of the United States - macrobenthic invertebrate fauna of the Middle Atlantic Bight region faunal composition and quantitative distribution. U.S. Geol. Surv. Prof. Pap., No. 529-N, 198 p.

WISSING, T. E., R. M. DARNELL, M. A. IBRAHIM, and L. BERNER Jr. 1973. Caloric values of marine animals from the Gulf of Mexico. Contrib. Mar. Sci., 17: 1-7. 


\section{Appendix}

Energy equivalents of 151 marine organisms from the continental shelf of the Northwest Atlantic from Nova Scotia to North Carolina. Values are for whole bodies except where specified by footnotes. Shell weight as percentage of total body weight is given for each species analyzed with shells removed.

\begin{tabular}{|c|c|c|c|c|c|c|c|c|}
\hline \multirow[b]{2}{*}{ Taxa } & \multirow{2}{*}{$\begin{array}{c}\text { No. of } \\
\text { combus- } \\
\text { tions }\end{array}$} & \multirow{2}{*}{$\begin{array}{c}\text { Dry } \\
\text { weight } \\
\% \text { ash }\end{array}$} & \multirow[b]{2}{*}{$\% \mathrm{H}_{2} \mathrm{O}$} & \multicolumn{2}{|c|}{$\begin{array}{c}\text { Dry weight } \\
\mathrm{KJ} / \mathrm{g}\end{array}$} & \multirow{2}{*}{$\begin{array}{c}\text { Dry weight } \\
\text { ash free } \\
\mathrm{KJ} / \mathrm{g}\end{array}$} & \multirow{2}{*}{$\begin{array}{c}\text { Wet } \\
\text { weight } \\
\mathrm{KJ} / \mathrm{g}\end{array}$} & \multirow{2}{*}{$\begin{array}{l}\% \text { shel } \\
\text { weight }\end{array}$} \\
\hline & & & & Mean & SD & & & \\
\hline \multicolumn{9}{|l|}{ Porifera } \\
\hline Suberites ficus & 3 & 52 & 87 & 11.6 & 0.4 & 23.9 & 1.5 & \\
\hline \multicolumn{9}{|l|}{ Cnidaria } \\
\hline \multicolumn{9}{|l|}{ Hydrozoa } \\
\hline Syncoryne sp. & 3 & 61 & 75 & 7.4 & 0.4 & 19.0 & 1.9 & \\
\hline \multicolumn{9}{|l|}{ Scyphozoa } \\
\hline Cyanea cappilata & 5 & 45 & 99 & 11.8 & 0.7 & 21.5 & 0.1 & \\
\hline Aurelia aurita & 6 & 48 & 95 & 8.8 & 0.7 & 16.3 & 0.4 & \\
\hline \multicolumn{9}{|l|}{ Anthozoa } \\
\hline Renilla reniformis & 3 & 40 & 58 & 6.4 & 0.1 & 10.7 & 2.7 & \\
\hline Metridium senile & 3 & 11 & 84 & 18.0 & 0.1 & 20.3 & 2.9 & \\
\hline Ceriantheopsis americanus & 12 & 14 & 75 & 18.4 & 0.6 & 21.3 & 4.7 & \\
\hline \multicolumn{9}{|l|}{ Rhynchocoela } \\
\hline Cerebratulus sp. & 7 & 10 & 78 & 23.2 & 0.4 & 23.3 & 4.6 & \\
\hline \multicolumn{9}{|l|}{ Bryozoa } \\
\hline Bugula flabellata & 5 & 69 & 72 & 8.2 & 0.7 & 26.5 & 2.3 & \\
\hline Brachiopoda & & & & & & & & \\
\hline Terebratulina septentrionalis & 4 & 91 & 67 & 7.6 & 0.7 & $\cdots$ & 2.5 & $(24)$ \\
\hline Mollusca & & & & & & & & \\
\hline Gastropoda & & & & & & & & \\
\hline Polinices heros & $8^{\mathrm{a}}$ & 10 & 67 & 19.9 & 0.7 & 22.0 & 5.9 & $(46)$ \\
\hline Buccinum undatum & $8^{a}$ & 10 & 57 & 18.7 & 0.9 & 19.9 & 7.7 & $(60)$ \\
\hline Colus stimpsoni & $4^{a}$ & 13 & 72 & 18.5 & 0.5 & 20.6 & 5.2 & $(61)$ \\
\hline Colus pygmaeus & 4 & 88 & 73 & 3.5 & 0.2 & 22.7 & 0.9 & \\
\hline Neptunea lyrata & $7^{\mathrm{a}}$ & 13 & & 18.2 & 0.3 & 21.0 & $\ldots$ & \\
\hline Busycon carica & $3^{\mathrm{a}}$ & 10 & 73 & 18.3 & 0.01 & 20.2 & 4.9 & $(64)$ \\
\hline Busycon canaliculatum & $5^{\mathrm{a}}$ & 9 & 73 & 19.9 & 0.3 & 21.9 & 5.4 & $(50)$ \\
\hline Lamelledorididae & 3 & 21 & 78 & 19.4 & 0.04 & 24.6 & 4.3 & \\
\hline Bivalvia & & & & & & & & \\
\hline Nucula proxima & $3^{a}$ & 15 & 84 & 20.4 & 0.2 & 24.0 & 3.3 & $(43)$ \\
\hline Nucula proxima & 4 & 84 & 40 & 3.7 & 0.3 & 23.1 & 2.2 & \\
\hline Modiolus modiolus & $8^{\mathrm{a}}$ & 12 & 78 & 19.8 & 0.7 & 22.6 & 4.3 & $(52)$ \\
\hline Chlamys islandicus & $3^{\mathrm{a}}$ & 16 & 73 & 19.5 & 0.4 & 23.2 & 5.3 & (50) \\
\hline Placopecten magellanicus & $15^{\mathrm{a}}$ & 15 & 78 & 18.5 & 0.4 & 21.8 & 3.0 & (44) \\
\hline Astarte undata & $14^{\mathrm{a}}$ & 12 & 67 & 18.0 & 0.8 & 21.3 & 6.2 & (80) \\
\hline Cyclocardia borealis & $8^{a}$ & 27 & 90 & 14.0 & 0.8 & 19.2 & 1.3 & (74) \\
\hline Arctica is/andica & $294^{\mathrm{a}}$ & 20 & 88 & 15.4 & 0.2 & 19.7 & 1.6 & (48) \\
\hline Spisula solidissima & $21^{\mathrm{a}}$ & 18 & 81 & 16.5 & 0.3 & 20.2 & 2.9 & (42) \\
\hline Ensis directus & $3^{a}$ & $\ldots$ & 83 & 16.8 & 0.1 & $\ldots$ & 2.9 & (30) \\
\hline Periploma leanum & 2 & $\ldots$ & 74 & 4.8 & 0.2 & $\ldots$ & 0.3 & \\
\hline Cephalopoda & & & & & & & & \\
\hline Illex illecebrosus & 10 & 7 & 69 & 22.0 & 0.7 & 23.6 & 7.1 & \\
\hline Loligo pealei & 14 & 8 & 72 & 20.4 & 0.5 & 21.4 & 5.6 & \\
\hline Lolliguncula brevis & 3 & 14 & 82 & 21.3 & 0.1 & 24.5 & 3.8 & \\
\hline Octopus vulgaris & 11 & 19 & $\ldots$ & 17.9 & 1.6 & 20.0 & $\ldots$ & \\
\hline Annelida & & & & & & & & \\
\hline Polychaeta & & & & & & & & \\
\hline Aphrodita hastata & 18 & 34 & 81 & 13.4 & 0.6 & 20.1 & 2.4 & \\
\hline Glycera americana & 3 & 12 & 79 & 18.8 & 0.2 & 21.8 & 4.0 & \\
\hline Ophioglycera gigantea & 3 & 12 & 83 & 19.6 & 0.5 & 23.3 & 3.3 & \\
\hline Nephtys incisa & 13 & 16 & 74 & 17.9 & 1.0 & 22.3 & 4.4 & \\
\hline Aglaophamus igalis & 5 & 21 & 76 & 15.9 & 6.3 & 20.2 & 3.8 & \\
\hline Ophelia bicornis & 5 & 64 & $\ldots$ & 7.5 & 0.6 & 21.1 & $\ldots$ & \\
\hline Ophelia denticulata & 5 & 56 & 64 & 13.5 & 0.8 & 30.3 & 4.9 & \\
\hline Lumbrineris fragilis & 2 & - & 65 & 21.3 & 0.1 & $\ldots$ & 4.7 & \\
\hline Terebellides stroemis & 3 & 12 & 58 & 16.4 & 0.1 & 18.6 & 6.9 & \\
\hline Pherusa affinis & 21 & 43 & 39 & 14.4 & 0.9 & 23.7 & 7.6 & \\
\hline Chone infundibuliformis & 5 & 11 & 76 & 16.0 & 0.4 & 18.0 & 3.8 & \\
\hline
\end{tabular}


Appendix (continued)

\begin{tabular}{|c|c|c|c|c|c|c|c|}
\hline \multirow[b]{2}{*}{ Taxa } & \multirow{2}{*}{$\begin{array}{l}\text { No. of } \\
\text { combus- } \\
\text { tions }\end{array}$} & \multirow{2}{*}{$\begin{array}{c}\text { Dry } \\
\text { weight } \\
\% \text { ash }\end{array}$} & \multirow[b]{2}{*}{$\% \mathrm{H}_{2} \mathrm{O}$} & $\begin{array}{c}\text { Dry weight } \\
\mathrm{KJ} / \mathrm{g}\end{array}$ & \multirow{2}{*}{$\begin{array}{c}\text { Dry weight } \\
\text { ash free } \\
\mathrm{KJ} / \mathrm{g}\end{array}$} & \multirow{2}{*}{$\begin{array}{c}\text { Wet } \\
\text { weight } \\
\mathrm{KJ} / \mathrm{g}\end{array}$} & \multirow{2}{*}{$\begin{array}{l}\% \text { shell } \\
\text { weight }\end{array}$} \\
\hline & & & & Mean & & & \\
\hline
\end{tabular}

\section{Arthropoda}

Crustacea

Stomatopoda

Squilla empusa

Amphipoda

Hyperia galba

Ampelisca agassizi

Unciola irrorata

Gammarus annulatus

Leptocheirus pinguis

Mysidacea

Neomysis americana

Euphausidacea

Meganyctiphanes norvegica

Decapoda

Penaeus aztecus

Sicyona typica

Pasiphaea tarda

Paleomonetes vulgaris

Dichelopandalus leptocerus

Crangon septemspinosa

Homarus americanus

Pagurus acadianus

Pagurus bernhardus

Pagurus pollicarpus

Hyas araneus

Libinia emarginata

Pelia mutica

Cancer irroratus

Eurypanopeus depressus

$\begin{array}{rrrrrrr}15 & 28 & 61 & 15.3 & 1.1 & 21.0 & 5.8 \\ 8 & 26 & 80 & 18.6 & 1.2 & 24.7 & 3.6 \\ 7 & 47 & 22 & 10.5 & 0.6 & 18.5 & 8.8 \\ 4 & 41 & 20 & 13.9 & 0.7 & 33.0 & 11.1 \\ 8 & 67 & 88 & 13.7 & 0.6 & 18.4 & 1.7 \\ 4 & 51 & 64 & 5.9 & 0.3 & 12.0 & 2.0 \\ & & & & & & \\ 4 & \ldots & \ldots & 16.1 & 2.0 & \ldots & \ldots \\ & & & & & & \\ 15 & 22 & 82 & 19.4 & 0.7 & 24.9 & 3.4 \\ & & & & & & \\ 5 & 16 & 51 & 18.2 & 0.5 & 21.6 & 8.9 \\ 5 & 26 & 66 & 14.4 & 0.2 & 19.4 & 4.9 \\ 5 & 18 & \ldots & 18.7 & 0.7 & 22.7 & \ldots \\ 8 & 17 & 75 & 14.7 & 0.6 & 21.9 & 4.6 \\ 28 & 22 & 70 & 18.7 & 0.6 & 24.5 & 5.5 \\ 26 & 28 & 79 & 16.2 & 0.6 & 18.4 & 3.7 \\ 5 & 36 & 68 & 13.8 & 1.4 & 21.6 & 4.8 \\ 5 & 28 & 63 & 18.5 & 1.6 & 22.7 & 6.9 \\ 4 & 34 & 57 & 14.1 & 1.1 & 21.3 & 6.0 \\ 5 & 41 & 63 & 18.4 & 0.2 & 30.3 & 6.6 \\ 10 & 55 & 67 & 8.5 & 0.4 & 18.0 & 2.8 \\ 11 & 45 & 63 & 12.6 & 0.5 & 19.9 & 5.4 \\ 3 & 51 & 66 & 10.3 & 0.1 & 21.1 & 3.3 \\ 15 & 41 & 70 & 12.8 & 0.9 & 20.7 & 3.7 \\ 5 & 50 & \ldots & 4.5 & 1.9 & 9.0 & \ldots\end{array}$

Echinodermata

Holothuroidea

Cucumaria frondosa

Thyone scabra

Caudina arenata

Echinoidea

Arbacia punctulata

Strongylocentrotus droebachiensis

Echinarachnius parma

Moira atropos

Stelleroidea

Ctenodiscus crispatus

Henricia sp.

Asteria forbesi

Leptasterias tenera

Ophioderma brevispina

Ophiopholis aculeata

15

$\begin{array}{rr}14.1 & 0.6 \\ 6.0 & 0.2\end{array}$

16.6

20.6

23.6

3.4

37

$14.9 \quad 0.1$

28.0

$\begin{array}{ll}2.8 & 0.3\end{array}$

$5.1 \quad 0.6$

28.0

24.0

23.3

5.8

Chordata

Tunicata

Amaroucium pellucidum

Ascidia callosa

Boltenia ovifera

Molgula manhattensis

$$
\text { Salpidae }
$$

$\begin{array}{ll}3.5 & 0.2\end{array}$

23.6

$\begin{array}{rrrr}9.2 & 0.2 & 23.6 & 2.8 \\ 9.8 & 1.2 & 17.2 & 3.4 \\ 7.2 & 0.3 & 20.5 & 2.2 \\ 10.7 & 0.4 & 21.0 & 3.1 \\ 3.7 & 0.2 & 17.6 & 2.1 \\ 4.7 & 0.4 & 14.7 & 1.8\end{array}$

Pisces

Chondrichthyes

Isurus oxyrhinchus

Lamna nasus

Carcharhinus plumbeus

Prionace glauca

Squalus acanthias

Raja erinacea

\begin{tabular}{|c|c|}
\hline$\ldots$ & 20.6 \\
\hline$\cdots$ & 20.0 \\
\hline 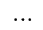 & 19.9 \\
\hline & 18.4 \\
\hline 67 & 25.8 \\
\hline 2 & 17.6 \\
\hline
\end{tabular}


Appendix (continued)

\begin{tabular}{|c|c|c|c|c|c|c|c|c|}
\hline \multirow[b]{2}{*}{ Taxa } & \multirow{2}{*}{$\begin{array}{c}\text { No. of } \\
\text { combus- } \\
\text { tions }\end{array}$} & \multirow{2}{*}{$\begin{array}{l}\text { Dry } \\
\text { weight } \\
\% \text { ash }\end{array}$} & \multirow[b]{2}{*}{$\% \mathrm{H}_{2} \mathrm{O}$} & \multicolumn{2}{|c|}{$\begin{array}{c}\text { Dry weight } \\
\mathrm{KJ} / \mathrm{g} \\
\end{array}$} & \multirow{2}{*}{$\begin{array}{c}\text { Dry weight } \\
\text { ash free } \\
\mathrm{KJ} / \mathrm{g}\end{array}$} & \multirow{2}{*}{$\begin{array}{c}\begin{array}{c}\text { Wet } \\
\text { weight } \\
\mathrm{KJ} / \mathrm{g}\end{array} \\
\end{array}$} & \multirow{2}{*}{$\begin{array}{l}\% \text { shell } \\
\text { weight }\end{array}$} \\
\hline & & & & Mean & SD & & & \\
\hline \multicolumn{9}{|l|}{ Osteichthyes } \\
\hline Conger oceanicus & 6 & 8 & 67 & 29.8 & 1.7 & 32.4 & 9.8 & \\
\hline Ophichthus cruentifier & 4 & 14 & 71 & 19.8 & 0.8 & 22.9 & 5.8 & \\
\hline Alosa sapidissima & 5 & 11 & 75 & 19.6 & 0.5 & 22.1 & 4.9 & \\
\hline Alosa aestivalis & 15 & 12 & 69 & 22.2 & 0.7 & 25.0 & 7.7 & \\
\hline Alosa mediocris & 5 & 11 & 74 & 21.1 & 0.4 & 23.8 & 5.5 & \\
\hline Alosa pseudoharengus & 24 & 12 & 71 & 21.7 & 0.5 & 24.5 & 6.4 & \\
\hline Clupea harengus & 20 & 8 & 57 & 25.1 & 2.3 & 27.2 & 10.6 & \\
\hline Brevoortia tyrannus & 10 & 13 & 65 & 21.4 & 0.4 & 24.6 & 7.5 & \\
\hline Etrumeus teres & 17 & 14 & 73 & 20.4 & 0.5 & 23.6 & 5.5 & \\
\hline Opisthonema oglinum & 5 & 11 & 74 & 24.8 & 0.9 & 27.7 & 6.4 & \\
\hline Sardinella aurita & 5 & 14 & 70 & 19.9 & 0.1 & 23.1 & 6.0 & \\
\hline Anchoa hepsetus & 24 & 16 & 71 & 19.9 & 0.4 & 23.6 & 5.8 & \\
\hline Anchoa mitchilli & 5 & 14 & 72 & 21.2 & 0.5 & 24.6 & 5.9 & \\
\hline Synodus foetens & 5 & 17 & 75 & 18.3 & 0.5 & 22.1 & 4.6 & \\
\hline Lophius americanus & 6 & 13 & 91 & 18.5 & 0.8 & 21.3 & 1.7 & \\
\hline Gadus morhua & 9 & 16 & 78 & 18.2 & 0.3 & 21.6 & 4.2 & \\
\hline Pollachius virens & 5 & 13 & 74 & 19.2 & 1.8 & 21.9 & 5.0 & \\
\hline Urophycis chuss & 10 & 14 & 80 & 19.4 & 0.5 & 22.6 & 3.8 & \\
\hline Urophycis regia & 3 & 10 & 78 & 21.3 & 0.7 & 23.6 & 4.7 & \\
\hline Urophycis tenuis & 3 & 14 & 67 & 19.2 & 0.3 & 22.3 & 6.3 & \\
\hline Melanogrammus aeglefinus & 4 & 17 & 78 & 20.3 & 0.7 & 24.3 & 4.5 & \\
\hline Enchelyopus cimbrius & 5 & 16 & 80 & 18.0 & 0.6 & 21.6 & 3.6 & \\
\hline Merluccius bilinearis & 10 & 13 & 79 & 21.3 & 0.3 & 24.6 & 4.6 & \\
\hline Macrozoarces americanus & 9 & 13 & 76 & 19.2 & 0.2 & 22.0 & 4.7 & \\
\hline Scomberesox saurus & 5 & 9 & 62 & 22.3 & 0.7 & 24.6 & 8.5 & \\
\hline Menidia menidia & 10 & 13 & 66 & 21.2 & 0.7 & 24.4 & 7.3 & \\
\hline Sebastes marinus & 15 & 20 & 75 & 18.5 & 1.1 & 23.1 & 4.4 & \\
\hline Prionotus carolinus & 5 & 22 & 75 & 17.7 & 1.1 & 22.7 & 4.4 & \\
\hline Hemitripterus americanus & 6 & 16 & 86 & 18.1 & 0.5 & 21.5 & 2.5 & \\
\hline Myoxocephalus octodecemspinosus & 5 & 17 & 74 & 20.8 & 0.6 & 25.1 & 5.4 & \\
\hline Triglops murrayi & 5 & 16 & 80 & 18.1 & 0.6 & 21.5 & 3.6 & \\
\hline Triglops nybelini & 5 & 14 & 73 & 19.4 & 1.2 & 22.5 & 5.2 & \\
\hline Citharichthys arctifrons & 5 & 14 & 78 & 19.4 & 0.2 & 22.5 & 4.3 & \\
\hline Paralichthys oblongus & 10 & 13 & 75 & 22.0 & 0.3 & 25.4 & 5.5 & \\
\hline Scophthalmus aquosus & 3 & 13 & 86 & 22.2 & 0.2 & 25.4 & 3.1 & \\
\hline Hippoglossoides platessoides & 3 & 15 & 77 & 17.7 & 0.2 & 21.0 & 4.1 & \\
\hline Limanda ferruginea & 12 & 16 & 75 & 17.6 & 0.6 & 20.9 & 4.4 & \\
\hline Liopsetta putnami & 5 & 17 & 78 & 17.1 & 0.1 & 20.7 & 3.8 & \\
\hline Pseudopleuronectes americanus & 5 & 15 & 78 & 16.4 & 0.6 & 19.4 & 3.6 & \\
\hline Symphurus plagiusa & 4 & 16 & 67 & 19.0 & 0.7 & 22.7 & 6.3 & \\
\hline Sphoeroides maculatus & 4 & 15 & 74 & 19.4 & 1.2 & 22.8 & 5.1 & \\
\hline Pomatomus saltatrix & 5 & 20 & 77 & 20.8 & 0.8 & 25.0 & 4.8 & \\
\hline Caranx chrysos & 5 & 16 & 68 & 17.7 & 0.3 & 21.1 & 5.7 & \\
\hline Chloroscombrus chrysurus & 5 & 14 & 63 & 23.9 & 0.5 & 27.9 & 8.8 & \\
\hline Selar crumenopthalmus & 5 & 14 & 70 & 16.4 & 6.9 & 19.0 & 4.9 & \\
\hline Seriola dumerili & 3 & 15 & 75 & 18.4 & 0.4 & 21.5 & 4.6 & \\
\hline Decapterus punctatus & 5 & 13 & 68 & 18.8 & 0.4 & 21.6 & 6.0 & \\
\hline Stenotomus chrysops & 14 & 16 & 73 & 21.5 & 0.2 & 25.6 & 6.1 & \\
\hline Cynoscion regalis & 4 & 13 & 76 & 20.1 & 0.7 & 23.0 & 4.8 & \\
\hline Leiostomus xanthurus & 11 & 17 & 65 & 20.1 & 0.5 & 24.0 & 7.0 & \\
\hline Tautogolabrus adspersus & 5 & 11 & 70 & 22.2 & 0.5 & 24.9 & 6.6 & \\
\hline Lumpenus maculatus & 8 & 12 & 71 & 20.2 & 0.6 & 22.2 & 5.6 & \\
\hline Ammodytes americanus & 20 & 12 & 69 & 21.7 & 0.6 & 24.8 & 6.8 & \\
\hline Scomber japonicus & 15 & 12 & 71 & 21.6 & 0.2 & 24.4 & 6.2 & \\
\hline Scomber scombrus & 28 & 8 & 75 & 24.1 & 1.9 & 26.2 & 6.0 & \\
\hline Thunnus albacares & $6^{d}$ & $\ldots$ & $\ldots$ & 23.4 & 0.6 & $\ldots$ & $\cdots$ & \\
\hline Acanthocybium solanderi & $6^{\mathrm{b}}$ & 6 & $\ldots$ & 23.4 & 1.5 & 24.9 & $\ldots$ & \\
\hline Xiphias gladius & $5^{e}$ & 4 & $\ldots$ & 27.5 & 0.6 & 28.8 & $\ldots$ & \\
\hline Peprilus triacanthus & 25 & 11 & 74 & 24.2 & 0.3 & 27.2 & 6.2 & \\
\hline Peprilus alepidotus & 5 & 11 & 73 & 22.9 & 0.4 & 25.8 & 6.2 & \\
\hline \multicolumn{9}{|l|}{ Cetacea } \\
\hline Lagenorhynchus acutus & $8^{\mathrm{e}}$ & 1 & $\ldots$ & 33.3 & 0.7 & 33.6 & $\ldots$ & \\
\hline
\end{tabular}

a Without shell. ${ }^{\mathrm{b}}$ Dorsal section without skin. ${ }^{\mathrm{c}}$ Middle section including viscera. ${ }^{\mathrm{d}}$ Mixed muscle fillet without skin. ${ }^{\mathrm{e}}$ Dorsal section with skin. 


\section{Appendix}

Energy equivalents of 151 marine organisms from the continental shelf of the Northwest Atlantic from Nova Scotia to North Carolina. Values are for whole bodies except where specified by footnotes. Shell weight as percentage of total body weight is given for each species analyzed with shells removed.

\begin{tabular}{|c|c|c|c|c|c|c|c|c|}
\hline \multirow[b]{2}{*}{ Taxa } & \multirow{2}{*}{$\begin{array}{c}\text { No. of } \\
\text { combus- } \\
\text { tions }\end{array}$} & \multirow{2}{*}{$\begin{array}{c}\text { Dry } \\
\text { weight } \\
\% \text { ash }\end{array}$} & \multirow[b]{2}{*}{$\% \mathrm{H}_{2} \mathrm{O}$} & \multicolumn{2}{|c|}{$\begin{array}{c}\text { Dry weight } \\
\mathrm{KJ} / \mathrm{g}\end{array}$} & \multirow{2}{*}{$\begin{array}{c}\text { Dry weight } \\
\text { ash free } \\
\mathrm{KJ} / \mathrm{g}\end{array}$} & \multirow{2}{*}{$\begin{array}{c}\text { Wet } \\
\text { weight } \\
\mathrm{KJ} / \mathrm{g}\end{array}$} & \multirow{2}{*}{$\begin{array}{l}\% \text { shel } \\
\text { weight }\end{array}$} \\
\hline & & & & Mean & SD & & & \\
\hline \multicolumn{9}{|l|}{ Porifera } \\
\hline Suberites ficus & 3 & 52 & 87 & 11.6 & 0.4 & 23.9 & 1.5 & \\
\hline \multicolumn{9}{|l|}{ Cnidaria } \\
\hline \multicolumn{9}{|l|}{ Hydrozoa } \\
\hline Syncoryne sp. & 3 & 61 & 75 & 7.4 & 0.4 & 19.0 & 1.9 & \\
\hline \multicolumn{9}{|l|}{ Scyphozoa } \\
\hline Cyanea cappilata & 5 & 45 & 99 & 11.8 & 0.7 & 21.5 & 0.1 & \\
\hline Aurelia aurita & 6 & 48 & 95 & 8.8 & 0.7 & 16.3 & 0.4 & \\
\hline \multicolumn{9}{|l|}{ Anthozoa } \\
\hline Renilla reniformis & 3 & 40 & 58 & 6.4 & 0.1 & 10.7 & 2.7 & \\
\hline Metridium senile & 3 & 11 & 84 & 18.0 & 0.1 & 20.3 & 2.9 & \\
\hline Ceriantheopsis americanus & 12 & 14 & 75 & 18.4 & 0.6 & 21.3 & 4.7 & \\
\hline \multicolumn{9}{|l|}{ Rhynchocoela } \\
\hline Cerebratulus sp. & 7 & 10 & 78 & 23.2 & 0.4 & 23.3 & 4.6 & \\
\hline \multicolumn{9}{|l|}{ Bryozoa } \\
\hline Bugula flabellata & 5 & 69 & 72 & 8.2 & 0.7 & 26.5 & 2.3 & \\
\hline Brachiopoda & & & & & & & & \\
\hline Terebratulina septentrionalis & 4 & 91 & 67 & 7.6 & 0.7 & $\cdots$ & 2.5 & $(24)$ \\
\hline Mollusca & & & & & & & & \\
\hline Gastropoda & & & & & & & & \\
\hline Polinices heros & $8^{\mathrm{a}}$ & 10 & 67 & 19.9 & 0.7 & 22.0 & 5.9 & $(46)$ \\
\hline Buccinum undatum & $8^{a}$ & 10 & 57 & 18.7 & 0.9 & 19.9 & 7.7 & $(60)$ \\
\hline Colus stimpsoni & $4^{a}$ & 13 & 72 & 18.5 & 0.5 & 20.6 & 5.2 & $(61)$ \\
\hline Colus pygmaeus & 4 & 88 & 73 & 3.5 & 0.2 & 22.7 & 0.9 & \\
\hline Neptunea lyrata & $7^{\mathrm{a}}$ & 13 & & 18.2 & 0.3 & 21.0 & $\ldots$ & \\
\hline Busycon carica & $3^{\mathrm{a}}$ & 10 & 73 & 18.3 & 0.01 & 20.2 & 4.9 & $(64)$ \\
\hline Busycon canaliculatum & $5^{\mathrm{a}}$ & 9 & 73 & 19.9 & 0.3 & 21.9 & 5.4 & $(50)$ \\
\hline Lamelledorididae & 3 & 21 & 78 & 19.4 & 0.04 & 24.6 & 4.3 & \\
\hline Bivalvia & & & & & & & & \\
\hline Nucula proxima & $3^{a}$ & 15 & 84 & 20.4 & 0.2 & 24.0 & 3.3 & $(43)$ \\
\hline Nucula proxima & 4 & 84 & 40 & 3.7 & 0.3 & 23.1 & 2.2 & \\
\hline Modiolus modiolus & $8^{\mathrm{a}}$ & 12 & 78 & 19.8 & 0.7 & 22.6 & 4.3 & $(52)$ \\
\hline Chlamys islandicus & $3^{\mathrm{a}}$ & 16 & 73 & 19.5 & 0.4 & 23.2 & 5.3 & (50) \\
\hline Placopecten magellanicus & $15^{\mathrm{a}}$ & 15 & 78 & 18.5 & 0.4 & 21.8 & 3.0 & (44) \\
\hline Astarte undata & $14^{\mathrm{a}}$ & 12 & 67 & 18.0 & 0.8 & 21.3 & 6.2 & (80) \\
\hline Cyclocardia borealis & $8^{a}$ & 27 & 90 & 14.0 & 0.8 & 19.2 & 1.3 & (74) \\
\hline Arctica is/andica & $294^{\mathrm{a}}$ & 20 & 88 & 15.4 & 0.2 & 19.7 & 1.6 & (48) \\
\hline Spisula solidissima & $21^{\mathrm{a}}$ & 18 & 81 & 16.5 & 0.3 & 20.2 & 2.9 & (42) \\
\hline Ensis directus & $3^{a}$ & $\ldots$ & 83 & 16.8 & 0.1 & $\ldots$ & 2.9 & (30) \\
\hline Periploma leanum & 2 & $\ldots$ & 74 & 4.8 & 0.2 & $\ldots$ & 0.3 & \\
\hline Cephalopoda & & & & & & & & \\
\hline Illex illecebrosus & 10 & 7 & 69 & 22.0 & 0.7 & 23.6 & 7.1 & \\
\hline Loligo pealei & 14 & 8 & 72 & 20.4 & 0.5 & 21.4 & 5.6 & \\
\hline Lolliguncula brevis & 3 & 14 & 82 & 21.3 & 0.1 & 24.5 & 3.8 & \\
\hline Octopus vulgaris & 11 & 19 & $\ldots$ & 17.9 & 1.6 & 20.0 & $\ldots$ & \\
\hline Annelida & & & & & & & & \\
\hline Polychaeta & & & & & & & & \\
\hline Aphrodita hastata & 18 & 34 & 81 & 13.4 & 0.6 & 20.1 & 2.4 & \\
\hline Glycera americana & 3 & 12 & 79 & 18.8 & 0.2 & 21.8 & 4.0 & \\
\hline Ophioglycera gigantea & 3 & 12 & 83 & 19.6 & 0.5 & 23.3 & 3.3 & \\
\hline Nephtys incisa & 13 & 16 & 74 & 17.9 & 1.0 & 22.3 & 4.4 & \\
\hline Aglaophamus igalis & 5 & 21 & 76 & 15.9 & 6.3 & 20.2 & 3.8 & \\
\hline Ophelia bicornis & 5 & 64 & $\ldots$ & 7.5 & 0.6 & 21.1 & $\ldots$ & \\
\hline Ophelia denticulata & 5 & 56 & 64 & 13.5 & 0.8 & 30.3 & 4.9 & \\
\hline Lumbrineris fragilis & 2 & - & 65 & 21.3 & 0.1 & $\ldots$ & 4.7 & \\
\hline Terebellides stroemis & 3 & 12 & 58 & 16.4 & 0.1 & 18.6 & 6.9 & \\
\hline Pherusa affinis & 21 & 43 & 39 & 14.4 & 0.9 & 23.7 & 7.6 & \\
\hline Chone infundibuliformis & 5 & 11 & 76 & 16.0 & 0.4 & 18.0 & 3.8 & \\
\hline
\end{tabular}

